\title{
Age, hepatitis B infection and risk of anti hepatitis B surface antigen
}

\author{
Bastaman Basuki
}

\begin{abstract}
Abstrak
Dalam makalah ini, yang merupakan sebagian hasil survei komunitas mengenai hepatitis di Jakarta, diungkapkan tentang prevalensi dan faktor risiko yang berkaitan dengan anti hepatitis B surface antigen (anti-HBs). Sampel terdiri dari 995 orang yang berumur 15 tahun keatas. Faktor risiko diidentifikasi dengan mempergunakan kuesioner, dan wawancara dilakukan di rumah subjek. Serum dianalisis terhadap anti-HBs, hepatitis B surface antigen (HBsAg), aspartate aminotransferase (AST), dan alanine aminotransferase (ALT). Hasil penelitian menunjukkan bahwa populasi terdiri dari penduduk yang relatif berpendidikan lebih tinggi. Seroprevalens anti-HBs positif adalah 17,5\% (174/995), dan HBsAg positif sebesar 4,1\% (4I/995). HBsAg positif memperkecil risiko anti-HBs positif (rasio odds suaian $=O R=0,24,95 \% \mathrm{CI}: 0,06-1,00, p=0,051$ ). Dibandingkan dengan golongan 15-19 tahun, terdapat kecenderungan positif yang bermakna bahwa golongan umur yang lebih tua berisiko lebih tinggi mengidap positif anti-HBs ( $p=0,004)$, dan mencapai puncaknya pada golongan umur 30-39 dan 40-49 tahun (masing-masing OR suaian =1,86; 95\% CI: 1,01-3,42, dan OR suaian $=2,19 ; 95 \%$ CI: 1,21-3,69). Kemudian terdapat penurunan risiko di antara penduduk yang lebih tua. Dapat disimpulkan bahwa seroprevalens anti-HBs moderat pada penduduk yang relatif berpendidikan tinggi. Status HBsAg positif memperkecil risiko anti-HBs positif, dan orang yang berumur lebih tua mempunyai kecenderungan berisiko anti-HBs positif.
\end{abstract}

\begin{abstract}
As part of a community-based hepatitis survey in Jakarta, this paper measures the prevalence of anti hepatitis $B$ surface antigen (anti-HBs), and identifies the related risk markers. Sample consisted of 995 people aged 15 years and above. Risk markers were identified by questionnaires and home visits, and serum was analyzed for anti-HBs, hepatitis B surface antigen (HBsAg), aspartate aminotransferase $(A S T)$, and alanine aminotransferase $(A L T)$. In a relatively higher educated population, the seroprevalence of anti-HBs positive was $17.5 \%$ (174/995), and HBsAg positive was $4.1 \%$ (41/995). A positive of HBsAg reduced the risk of positive anti-HBs (adjusted odds ratio $=O R=0.24,95 \% C I: 0.06-1.00 ; p=0.051)$. Compared to $15-19$ years age group, there was a significant positive trend that older age groups had increased risk of having anti-HBs positive $(p=0.004)$, and reach its peak among aged 30-39 years and 40-49 (adjusted $O R=1.86 ; 95 \% \mathrm{CI}: 1.01-3.42$, and adjusted $O R=2.19 ; 95 \% \mathrm{CI}: 1.21-3.69$ respectively). Afterward the risk was decreasing among elderly persons. In conclusion, the seroprevalence in a relatively well educated population of anti-HBs was moderate. A positive status of HBsAg was lowering the risk of anti-HBs positive, and the older age had a trend of higher risk of having anti-HBs positive.
\end{abstract}

Keywords: age, hepatitis $B$, risk of anti hepatitis B surface antigen

\section{INTRODUCTION}

In southeast Asia including Indonesia hepatitis B infection are still endemic. ${ }^{1}$ There were several serological methods to detect hepatitis B infection, including measuring the prevalence of serum hepatitis $B$ antigen ( $\mathrm{HBsAg}$ ), antibody to hepatitis B surface antigen (anti $\mathrm{HBs}$ ), antibody to hepatitis B core antigen (anti $\mathrm{HBc}$ ), and hepatitis $B$ virus desoxyribonucleic acid (HBvDNA). The present of anti-HBs indicates recovery of acute hepatitis $\mathrm{B}$ or immunization.

Three antigen-antibody systems have been identified for hepatitis B virus (HBV): HBsAg and anti-HBs,

Department of Community Medicine, University of Indonesia Faculty of Medicine, Jakarta, Indonesia core antigen and antibody ( $\mathrm{HBcAg}$ and anti-HBc), and hepatitis $B$ virus e antigen and hepatitis $B$ virus $e$ antigen and hepatitis $B$ virus antibody ( $\mathrm{HBeAg}$ and anti-HBe). ${ }^{1,2}$ Serological evidence of previous hepatitis infection varies depend on several factors, especially on age and socioeconomic class.

Most previous epidemiological studies of anti-HBs markers have focused on special groups such as hospital-based patients, hemophilia patients, and hospital workers, blood donors. Prior studies in high risk groups in southeast Asia suggest that the risk markers for hepatitis B may differ from those seen in Europe and in the United States. ${ }^{1,3}$ Epidemiological studies on hospital-based or special groups not really represent the general population. 
Even though the protective immunity follows hepatitis $B$ infection if anti-HBs develops and HBsAg is negative, but to identify this data needs a cohort study. In order to conduct a mass vaccination strategy, therefore based on a community-base study it is beneficially to study some risk markers for anti-HBs in the general population and to define the roles of age and $\mathrm{HBsAg}$ as risk markers of anti-HBs.

\section{METHODS}

This analysis was a part of the study which was conducted from January to June 1994 in an urban subdistrict of eastern part of Jakarta, Indonesia. The subdistrict consisted of 34666 people in 7017 households. In this study, it was selected 340 households randomly. All the household members aged 15 and more were asked to participate. A total of 1150 subjects from these households were eligible to participate in the study. Specially trained nurse-midwives visited the houses of the eligible subjects to evaluate their socieconomic status, and to invite the subjects to visit a local participating hospital for this study. The nurse-midwives then interviewed the subjects using structured questionnaire at the participating hospital regarding demographic characteristics and risk markers for anti-HBs.

Blood samples for HBsAg, anti-HBs, aspartate aminotranferase (AST), and alanine aminotransferase (ALT) were taken.

Laboratory markers under study included anti-HBs, HBsAg, AST and ALT levels. AST and ALT laboratory tests were carried out using laboratory kit tests from Boehringer Mannheim GMBH (normal AST level is less than $38 \mathrm{IU} / \mathrm{dl}$ for male, and less than $32 \mathrm{IU} / \mathrm{dl}$ for female; normal ALT level is less than 42 $\mathrm{IU} / \mathrm{dl}$ for male, and less than $32 \mathrm{IU} / \mathrm{dl}$ for female).

Tests for anti-HBs and HBsAg were done using reverse passive hemagglutination (PHA) and passive hemagglutination (RPHA) consecutively in Laboratoria Hepatika Mataram, Nusa Tenggara Barat Indonesia. All sera were collected and kept at -20 degrees Celsius prior to the assessment.

The characteristics of subjects included gender, age, education, socioeconomic status, ethnicity, family size, alcohol use. The medical risk markers including history of: jaundice, family jaundice, transfusion, operation, hepatitis B vaccination, normality status of AST, ALT, and HBsAg.
For this analysis based on logistic regression, for each subgroup of risk markers, the reference subgroups were the subgroup which had less or least likely risk of anti-HBs and coded 0 . The higher risk subgroup were coded 1 etc. $^{4}$

Age was divided into subgroup of: 15-19 years; 20-29 years; 30-39 years; $40-49$ years; $50-59$ years; and 6087 years. Level of education (high = study at college/university or higher level; middle = study at junior or senior high school; low = illiterate, capable of reading only, or study not beyond primary school). Socioeconomic status (high/middle/low) was determined by the evaluation of the nurse-midwife, based on the housing condition, ownership of transportation devices, ownership of housing appliances, and the availability of electricity. Ethnic group (Malayan/Chinese). Family size (1-2 persons/3-4 person $/ 5$ persons and over). Current alcohol use (no/yes), history of surgical operations (never/ever). History of jaundice (never/ever), family history of jaundice (never/ever/unknown). History of hepatitis B vaccination (never/ever). History of transfusion (never/ever). History of operation (ever/never).

Logistic regression analysis was used to control the confounding effects of other characteristics and exposures on the relationship to anti-HBs. ${ }^{5}$ Any variable whose univariat test has a $p$ value less than 0.25 will be considered as a candidate for the multivariate model along with all variable known biologic importance Characteristics that fulfilled this definition as confounder are included in the models presented. ${ }^{4,5}$ Odds ratios were estimated by the method of maximum likelihood, and their 95\% confidence intervals (CI) were based on the standard error of coefficient estimates using Egret software. ${ }^{6}$

This study was approved by the Ethics Committee of the Department of Internal Medicine Faculty of Medicine University of Indonesia. Informed consent was obtained from participants in this study.

\section{RESULTS}

A number of 1020 respondents out of 1150 invited subjects (89\%) participated in this study. We excluded 25 out of 1020 subjects $(2.5 \%)$ due to incomplete and/or conflicting data, leaving a total of 995 subjects.

The excluded 25 subjects consisted of 22 who had anti-HBs negative and 3 anti-HBs positive; $24 \mathrm{HBsAg}$ negative and 1 with $\mathrm{HBs} A g$ positive. By age group: 1 
person belongs to age group of $15-19$ years; 5 persons aged $20-29$ years; 6 persons aged $30-49$ years; 7 persons aged $40-49$ years; 3 persons aged $50-59$ years; and 5 persons aged $60-87$ years. By gender: 13 male and 12 female. By history of jaundice: 22 persons never had jaundice, 3 persons who ever had jaundice. By history of family jaundice: 22 never had, 1 ever had, and 2 unknown. By socioeconomic status the excluded subjects were as follows: 4 belonged to high-level socioeconomic status, 5 middle-level socioeconomic status, and 16 low-level socioeconomic status.

The excluded subjects in term of HBs status, age groups, history of jaundice and history of family jaundice, gender, and socioeconomic status, were not significantly different with the 995 subjects which included in this analysis.

The overall seroprevalence of anti-HBs was $17.5 \%$ (174/995).

The youngest subject was 15 years old which follow the criteria of inclusion for this community-based study, and the eldest subject was 87 years old. The biggest number percentage of the subjects came from the middle education level $(54.7 \%=544 / 995)$, followed by high education level of $21.3 \%$ (212/995), and with education low of $23.6 \%$ (235/995).

The high level of socioeconomic status of the subjects was $24.3 \%$ (242/995), and the middle class was 20.6 (205/995), however the largest number come from the low socioeconomic status of $55.1 \%$ (548/995).

The univariate analysis results showed that there was no statistical significant relationship in term of gender, education level, socioeconomic status, ethnicity, family size and alcohol use to anti-HBs status (Table 1).

It was also noted from the univariate analysis that there was no statistical significance relationship to anti-HBs status in term of history of: jaundice, family jaundice, transfusion, operation, hepatitis B vaccination, and it also for the normality status of AST and ALT. However HBs Ag status reduced the risk a positive anti-HBs by 0.23 times $(\mathrm{OR}=023,95 \% \mathrm{CI}: 0.06-0.98)$.

We assumed there were no acute hepatitis cases found in our study because the maximum range of AST and ALT among our subjects was less than 2.5 times the normal limits. The range of AST in our study was 11 to $92 \mathrm{U} / \mathrm{l}$, while ALT ranged from 9 to $87 \mathrm{U} / \mathrm{l}$. (Table 2).
Forty one subjects were tested positive for $\mathrm{HBs} \mathrm{Ag}$ and 954 were negative, giving an overall prevalence of positive $\mathrm{HBsAg} 4.1 \%$. Those who ever had hepatitis B immunization was 49 persons out of 995 subjects or $4,9 \%$. The univariate analysis showed that a positive result of $\mathrm{HBsAg}$ test decreased the risk of positive anti-HBs status.

Our data showed that the other medical risk markers (ever had jaundice, family history of jaundice, history of transfusion, history of operation, hepatitis B vaccination, and abnormality of ALT/AST level) was not significantly associated with anti-HBs (Table 2).

The result of a suitable model for anti-HBs consisted of variables of HBsAg status and age group to see the relationship among those risk markers was shown on Table 3.

Table 1. Relationship of some characteristics to anti hepatitis B surface antigen (anti-HBs)

\begin{tabular}{|c|c|c|c|c|c|c|}
\hline \multirow{3}{*}{$x^{2}$} & \multicolumn{4}{|c|}{ Anti-HBs status } & \multirow{3}{*}{ OR* } & \multirow{3}{*}{$95 \% \mathrm{CI}$} \\
\hline & \multicolumn{2}{|c|}{$\begin{array}{l}\text { Positive } \\
(\mathrm{N}=174)\end{array}$} & \multicolumn{2}{|c|}{$\begin{array}{l}\text { Negative } \\
(\mathrm{N}=821)\end{array}$} & & \\
\hline & $\mathrm{n}$ & $\%$ & n & $\%$ & & \\
\hline \multicolumn{7}{|l|}{ Gender } \\
\hline Male & 80 & 46.0 & 381 & 46.4 & 1.00 & (reference) \\
\hline Female & 84 & 54.0 & 440 & 53.6 & 1.02 & $0.72-1.43$ \\
\hline \multicolumn{7}{|l|}{ Education } \\
\hline High & 41 & 23.6 & 171 & 20.8 & 1.00 & (reference) \\
\hline Middle & 84 & 48.3 & 460 & 56.0 & 0.76 & $0.50-1.15$ \\
\hline Low & 48 & 27.6 & 186 & 23.8 & 1.07 & $0.67-1.71$ \\
\hline Unknown & 1 & 0.6 & 3 & 0.4 & 1.39 & $0.14-13.71$ \\
\hline \multicolumn{7}{|c|}{ Socioeconomic status } \\
\hline High & 41 & 23.6 & 201 & 24.5 & 1.00 & (reference) \\
\hline Middle & 31 & 17.8 & 174 & 21.2 & 0.87 & $0.53-1.45$ \\
\hline Low & 102 & 58.6 & 446 & 54.3 & 1.21 & $0.75-1.67$ \\
\hline \multicolumn{7}{|l|}{ Ethnic group } \\
\hline Malayan & 161 & 92.5 & 744 & 90.6 & 1.00 & (reference) \\
\hline Chinese & 13 & 7.5 & 77 & 9.4 & 0.78 & $0.40-1.49$ \\
\hline \multicolumn{7}{|l|}{ Family size } \\
\hline $1-2$ persons & 53 & 30.5 & 225 & 27.4 & 1.00 & (reference) \\
\hline $3-4$ persons & 67 & 38.5 & 325 & 39.6 & 0.88 & $0.59-1.30$ \\
\hline 5 persons and over & 54 & 31.0 & 271 & 33.0 & 0.85 & $0.56-1.29$ \\
\hline \multicolumn{7}{|l|}{ Alcohol use } \\
\hline No & 169 & 97.1 & 790 & 96.2 & 1.00 & (reference) \\
\hline Yes & 5 & 2.9 & 31 & 3.8 & 0.75 & $0.29-1.97$ \\
\hline
\end{tabular}

* Univariate analysis 
Table 2. Relationship of medical risk factors to anti hepatitis B surface antigen (anti-HBs) Anti-HBs status

\begin{tabular}{|c|c|c|c|c|c|c|}
\hline & \multicolumn{4}{|c|}{ Anti-HBs status } & \multirow{3}{*}{$\mathrm{OR}^{*}$} & \multirow{3}{*}{$95 \% \mathrm{CI}$} \\
\hline & \multicolumn{2}{|c|}{$\begin{array}{l}\text { Positive } \\
(N=174)\end{array}$} & \multicolumn{2}{|c|}{$\begin{array}{c}\text { Negative } \\
(\mathrm{N}=821)\end{array}$} & & \\
\hline & $\mathrm{n}$ & $\%$ & $\mathrm{n}$ & $\%$ & & \\
\hline \multicolumn{7}{|c|}{ Ever had jaundice } \\
\hline Never & 166 & 95.4 & 776 & 94.5 & 1.00 & (reference) \\
\hline Ever & 45 & 4.6 & 45 & 5.5 & 0.83 & $0.39-1.80$ \\
\hline \multicolumn{7}{|c|}{ History of family jaundice } \\
\hline None & 151 & 86.8 & 703 & 85.6 & 1.00 & (reference) \\
\hline Yes & 15 & 8.6 & 80 & 9.7 & 0.87 & $0.47-1.60$ \\
\hline Unknown & 8 & 4.6 & 38 & 4.6 & 0.98 & $0.41-2.24$ \\
\hline \multicolumn{7}{|c|}{ Transfusion history } \\
\hline Never & 160 & 92.0 & 779 & 94.9 & 1.00 & (reference) \\
\hline Ever & 14 & 8.0 & 42 & 5.1 & 1.62 & $0.87-3.04$ \\
\hline \multicolumn{7}{|c|}{ History of operation } \\
\hline Never & 147 & 84.5 & 705 & 85.9 & 1.00 & (reference) \\
\hline Ever & 27 & 15.5 & 116 & 14.1 & 1.12 & $0.70-1.76$ \\
\hline \multicolumn{7}{|c|}{ Hepatitis B vaccination } \\
\hline Never & 116 & 85.3 & 627 & 95.6 & 1.00 & (reference) \\
\hline Ever & 20 & 14.7 & 29 & 4.5 & & \\
\hline \multicolumn{7}{|l|}{$\mathrm{AST} \dagger$} \\
\hline Normal & 130 & 74.7 & 640 & 78.0 & 1.00 & (reference) \\
\hline Abnormal & 44 & 25.3 & 181 & 22.0 & 0.82 & $0.45-1.49$ \\
\hline \multicolumn{7}{|l|}{ ALT $\ddagger$} \\
\hline Normal & 160 & 92.0 & 742 & 90.4 & 1.00 & (reference) \\
\hline Abnormal & 14 & 8.0 & 79 & 9.6 & 1.20 & $0.82-1.75$ \\
\hline \multicolumn{7}{|c|}{ Hepatitis B surface antigen } \\
\hline Negative & $172^{\circ}$ & 98.9 & 782 & 95.2 & 1.00 & (reference) \\
\hline Positive & 2 & 1.1 & 39 & 4.8 & 0.23 & $0.06-0.98$ \\
\hline
\end{tabular}

* Univariate analysis

† AST, aspartate aminotransferase

$\ddagger$ ALT, alanine aminotransferase
Compared to HBsAg negative subgroup, the positive HBsAg subgroup had lower risk of having a positive anti-HBs, adjusted odds ratio for age group was 0.24 (95\% CI: 0.06-1.00; $\mathrm{p}=0.051$ ).

Compared to subgroup 15-19 years and adjusted for HBsAg status, there was a positive overall trend of the relationship between age groups and anti HBsAg status (test for trend $p=0.004$ ). The risk was significantly increased beginning the age group of 30-39 years (adjusted OR=1.86; $95 \%$ CI: $1.01-3.42)$. The $40-49$ years subgroup had 2.2 fold risk (adjusted $\mathrm{OR}=2.19 ; 95 \%$ CI: 1.21-3.69). And also the subgroup of 50-59 had risk of almost two times (adjusted OR=1.78; 95\% CI: 0.96$3.32 ; p=0.070)$.

\section{DISCUSSION}

There are several limitations that must be considered in the interpretation of our findings. First, this study was conducted in an urban population with high educational and socioeconomic status relative to urban areas of Indonesia. Thus, our results may underestimate the prevalence of anti-HBs in urban populations. In addition, our population was limited to subjects age 15 and over and the results for younger children are not known. We do not have data on tattooing as well as intravenous drug abuse and sexual transmission.

Our study had a number of methodological strengths, including large size and a community-based design. However, our participation rate was quite high (89\%), making it unlikely that selection bias has played any substantial role in our findings.

Table 3. Relationship of hepatitis B surface antigen and age groups to anti hepatitis B surface antigen (anti-HBs) Anti-HBs status

\begin{tabular}{|c|c|c|c|c|c|c|}
\hline & \multicolumn{4}{|c|}{ Anti-HBs status } & \multirow{3}{*}{$\mathrm{OR} *+$} & \multirow{3}{*}{$95 \% \mathrm{CI}$} \\
\hline & \multicolumn{2}{|c|}{ Positive $(N=174)$} & \multirow{2}{*}{$\frac{\text { Negative }}{\mathrm{n}}$} & \multirow{2}{*}{$\frac{(\mathrm{N}=821)}{\%}$} & & \\
\hline & $\mathrm{n}$ & $\%$ & & & & \\
\hline \multicolumn{7}{|c|}{ Hepatitis B surface antigen status } \\
\hline Negative & 172 & 98.9 & 782 & 95.2 & 1.00 & (reference) \\
\hline Positive & 2 & 1.1 & 39 & 4.8 & 0.24 & $0.06-1.00 \ddagger$ \\
\hline \multicolumn{7}{|l|}{ Age group } \\
\hline $15-19$ years & 19 & 10.9 & 133 & 16.2 & 1.00 & (reference) \\
\hline $20-29$ years & 30 & 17.2 & 230 & 28.0 & 0.92 & $0.50-1.69$ \\
\hline $30-39$ years & 35 & 20.1 & 131 & 16.0 & 1.86 & $1.01-3.42$ \\
\hline $40-49$ years & 42 & 24.1 & 135 & 16.4 & 2.19 & $1.21-3.69$ \\
\hline $50-59$ years & 31 & 17.8 & 120 & 14.6 & 1.78 & $0.96-3.32$ \\
\hline $60-87$ years & 17 & 9.8 & 17 & 8.8 & 1.64 & $0.80-3.35$ \\
\hline
\end{tabular}

Test for trend: $p=0.004$

* Odds ratio for hepatitis B surface antigen status adjusted for age group

$\dagger$ Odds ratio for age group adjusted for hepatitis B surface antigen status

$\ddagger \mathbf{p}=0.051$ 
The biggest number percentage of the sample were from the middle education level of $54.7 \%$, followed by high education level of $21.3 \%$. In general, only a small percentage of urban Indonesian people in 1994 who had middle education level was $13.6 \%$ and the high education level was $3.2 \%{ }^{7}$

The level of socioeconomic status of our subjects was higher than the average of general urban Indonesian people. Our data showed that the high socioeconomic level was $24.3 \%$, and the middle class was $20.6 \%$. Whereas in general, only a small number of urban Indonesian socioeconomic level with high socioeconomic status. $^{7}$

Beside the risk marker of $\mathrm{HBsAg}$, we studied other risk markers that have been reported to be associated with anti-HBs but none of these risk markers showed statistically significant associations. This non statistically difference was most likely due to a lower power. AntiHBs in this study was not related to socioeconomic status. This situation might be due to almost half of the subjects come from middle and high classes and relatively bigger number of middle and higher educated people. In general, education related to health status, therefore most likely minimize the risk of developing hepatitis infection.

The seroprevalence of anti-HBs in this communitybased study was $17.5 \%$ and HBsAg was $4.1 \%$. It can be considered into consideration pattern of hepatitis B intermediate prevalence rate (where childhood infection frequent and neonatal infection infrequent). ${ }^{8}$

In this community-based study are different from blood donor surveys on the prevalence of viral hepatitis. The other study in 1990 which consisted of 243 voluntary blood donors was performed in Jakarta. ${ }^{3}$ They found the prevalence of HBsAg to be $5.8 \%$ and anti-HBs to be $32.9 \%$. A large number of blood donor survey also found the prevalence of $\mathrm{HBsAg}$ among blood donors to be $5.5 \%{ }^{9}$ These differences illustrate the problems of comparing community-based studies with those derived from selected groups of blood donors.

Another community-based study consisted of 582 subjects in northern part of Jakarta (1995) where most of the subjects came from low socioeconomic status, low educated. ${ }^{10}$ They found the prevalence of anti-HBs and HBsAg were $25.0 \%$ and $2.7 \%$ respectively. The seroprevalence rates of anti-HBs was higher compared to our study. This may be due to different demographic characteristics (low socioeconomic class and lower educated status), and different serologic methods. The northern part of Jakarta study was using Elisa serologic test, while our study, tests for anti-HBs was done using passive hemagglutination (PHA). Elisa serologic test is more sensitive test than PHA test. ${ }^{11}$

Hepatitis B infection early in life is most frequently subclinical, while infection in adulthood more commonly results in clinical illness with substantially greater morbidity and occasional fatalities. 8,9

Our community-subjects with anti-HBs and $\mathrm{HBsAg}$ seroprevalence of $17.5 \%$ and $4.1 \%$ respectively can be considered into consideration pattern of hepatitis B intermediate prevalence rate, therefore active immunization remains as the most important method of achieving wide spread prevention and eventual elimination of hepatitis B. ${ }^{8}$ However, in order to maximize the benefit of immunization programs, it is necessary to be foci on the groups at high risk of hepatitis B virus (HBV) infection.

Our data revealed there is a significant positive trend (adjusted test for trend: $p=0.004$ ) between age group and risk of anti-HBs positive. The test for trend was adjusted for HBsAg status. This finding was similar with the northern part of Jakarta study.

Among our subjects aged of 15-19 years, only 19 out of $152(12.5 \%)$ persons positive for anti-HBs (Table 3 ). Since this small number of immune young ages toward HBV, and the seroprevalence of anti-HBs among and HBsAg among our subjects can be considered into intermediate, therefore $\mathrm{HBV}$ vaccination should be targeted to adolescents among our subjects. Selected vaccination of adolescents who had anti-HBs negative can be carried out by community health facilities and family physicians. ${ }^{2}$

Family physicians can have a mayor influence on the success of this immunization strategy, because family physicians provide comprehensive family health for their community, including obstetric, perinatal, adolescent and adults care, and most likely more familiar to the risk of hepatitis B infection among their clients.

\section{Acknowledgements}

I am grateful to Dr. Nurul Akbar for permitting me to use the data for this publication, to review earlier drafts of this manuscript, and provided many helpful comments that improved the final product. I am also thanks to Dr. Sarwono Waspadji and his field staff for high 
dedication in coordinating and performing the field study, and to Dr. Mulyanto for his support to assay HBsAg and anti-HBs in Laboratoria Hepatika Mataram Indonesia. Test kits for assays of AST and ALT were generously provided by Boehringer Mannheim GMBH.

\section{REFERENCES}

1. Benneson AS, editor. Control of communicable diseases in man. $15^{\text {th }}$ ed. Washington (DC). APHA; 1990.

2. Cossart YE. Virus hepatitis and its control. $1^{\text {st }}$ ed. London. Cassell \& Collier Macmillan Publisher; 1977.

3. Budihusodo U, Sulaiman HA, Akbar HN, Lesmana LA, Waspodo AS, et al. Seroepidemiology of $\mathrm{HBV}$ and $\mathrm{HCV}$ infection in Jakarta, Indonesia. Gastroenterology Japonica 1991; 26 (Suppl 3): 196-201.

4. Hosmer DW, Lemeshow S. Applied logistic regression. New York: John Wiley \& Sons; 1989.

5. Breslow NE, Day NE. Statistical methods in cancer research. Vol. I. The analysis of case-control studies. Lyon: IARC; 1980.
6. Statistics and epidemiology Research Corporation. Egret: Reference manual. Seattle: The corporation; 1990.

7. Ministry of Health of Indonesia. Health profile in Indonesia. Jakarta; 1996

8. Maynard JE. Hepatitis B epidemiologic considerations and strategies for intervention: General principles. In: Nishioka $\mathrm{K}$, Blumber BS, Ishida N, Koike K, editors. Hepatitis viruses and hepatocellular carcinoma. Tokyo: Academic Press; 1985. p. 135-141.

9. Sulaiman HA, Julitasari, Sie A, Rustam M, Melani W, et al. Prevalence of hepatitis B and C in healthy Indonesian blood donors. Trans Royal Soc Tropical Med Hygiene 1995; 89: 167-170.

10. Widjaya S. Epidemiology hepatitis B virus infection in an urban area in Jakarta, Indonesia: A hospital and population based study [dissertation]. Leuven: Katholieke Universiteit Leuven; 1996.

11. Noer HMS. Seroepidemiology and clinical pattern of virus hepatitis. In: Proceedings of scientific meeting of Indonesian association for the study of the liver; 1983 Aug 19-20; Jakarta, Indonesia. The Association; 1983.

12. Mahoney FJ, Bulkholder BT. Prevention of hepatitis B virus infection. Am Fam Physician. 1993;47:695-871. 